\title{
Cerebellopontine Angle Primary Choroid Plexus Carcinoma Present in an Adult: Case Report and Literature Review
}

Andrew J. Witten ${ }^{1}$, Stephen K. Mendenhall ${ }^{2}$, Logan S. DeWitt ${ }^{3}$, Alexander Vortmeyer ${ }^{3}$, Aaron CohenGadol $^{2}$

1. Neurological Surgery, Indiana University School of Medicine, Indianapolis, USA 2. Department of Neurological Surgery, Indiana University Health, Indianapolis, USA 3. Department of Pathology and Laboratory Medicine, Indiana University Health, Indianapolis, USA

Corresponding author: Aaron Cohen-Gadol, acohenmd@gmail.com

\begin{abstract}
Choroid plexus tumors (CPTs) are rare intraventricular neoplasms that primarily occur in children and are rare in adults. Of the CPT subtypes, choroid plexus carcinomas (CPC) are highly aggressive and malignant and of World Health Organization (WHO) Grade III. Dissemination through the cerebrospinal fluid space is the inevitable natural course of the disease.

In this case report, we present a 33-year-old female with a past medical history notable for schizophrenia and bipolar disease who suffered from left-sided acute vision loss and hearing loss. Magnetic resonance imaging (MRI) demonstrated multiple enhancing masses found in the left cerebellopontine angle (CPA), right internal auditory canal, the atrium of the left ventricle, and the left foramen of Monroe. After surgical decompression of the CPA tumor, the permanent final pathology was consistent with CPC.
\end{abstract}

To our knowledge, this is the first reported case of a primary CPC occurring within the CPA in an adult. The unique presentation and progression of this rare adult-onset CPC provide insight for the diagnosis and treatment of other rare instances of CPTs.

Review began 10/22/2020 Review ended 02/02/2021 Published 02/10/2021

\section{() Copyright 2021}

Witten et al. This is an open access article distributed under the terms of the Creative Commons Attribution License CC-BY 4.0., which permits unrestricted use, distribution, and reproduction in any medium, provided the original author and source are credited.
Categories: Pathology, Neurosurgery

Keywords: primary choroid plexus carcinoma, cerebellopontine angle tumor, adult

\section{Introduction}

Choroid plexus tumors (CPT) are rare and account for $0.3 \%-0.6 \%$ of all brain tumors [1]. CPTs include choroid plexus papilloma, atypical choroid plexus papilloma, and choroid plexus carcinoma (CPC). Of these subtypes, CPC is the most aggressive and malignant (World Health Organization (WHO) grade-III). CPC is primarily a pediatric disease but presents in about $20 \%$ of adults and accounts for $15 \%-20 \%$ of all choroid plexus tumors [2]. CPC is derived from modified ependymal cells and commonly presents with hydrocephalus related to ventricular obstruction. Metastatic lesions disseminate through the cerebrospinal fluid (CSF). In children, they frequently arise from the lateral ventricles and the fourth ventricle in adults. Rarely, they occur in the cerebellopontine angle (CPA), suprasellar region, or even in the sacral canal [3]. To the author's knowledge, we present the first adult case of CPC presenting in the CPA.

Additionally, we conducted a literature review of adult CPC to investigate tumor location, clinical features, symptom duration, surgical outcomes, and adjuvant therapy. A comprehensive search of the literature was performed using Google Scholar and PubMed without date restrictions. During the search, a variety of terms were used in Boolean logic, to include: (1) CPC; (2) adult; (3) CPA; and (4) CPTs. Peer-reviewed studies that focused on CPCs primarily in adult populations were included in the literature review.

\section{Case Presentation}

\section{Preoperative course}

The patient is a 33-year-old woman who presented to the emergency department with decreased left visual acuity, hearing loss in her left ear, and paresthesia on the left side of her face. Her past medical history was notable for schizophrenia, bipolar disorder, intravenous (IV) drug use, and a 30 pack-year smoking history. On physical exam, she had diminished vision in her left eye, hearing loss in her left ear, and mild aphasia; otherwise, she had a normal neurologic exam. Magnetic resonance imaging (MRI) revealed four lobulated heterogeneous enhancing masses in the left CPA, right internal auditory canal, the atrium of the left ventricle, and the left foramen of Monroe (Figure 1). The largest was in the CPA, measuring $2.1 \times 3.5 \times 3.1 \mathrm{~cm}$ with surrounding vasogenic edema. Computed tomography (CT) of the chest, abdomen, and pelvis and MRI total spine were negative for tumor. She was offered retrosigmoid craniotomy for open biopsy and cranial nerve decompression. 


\section{Cureus}

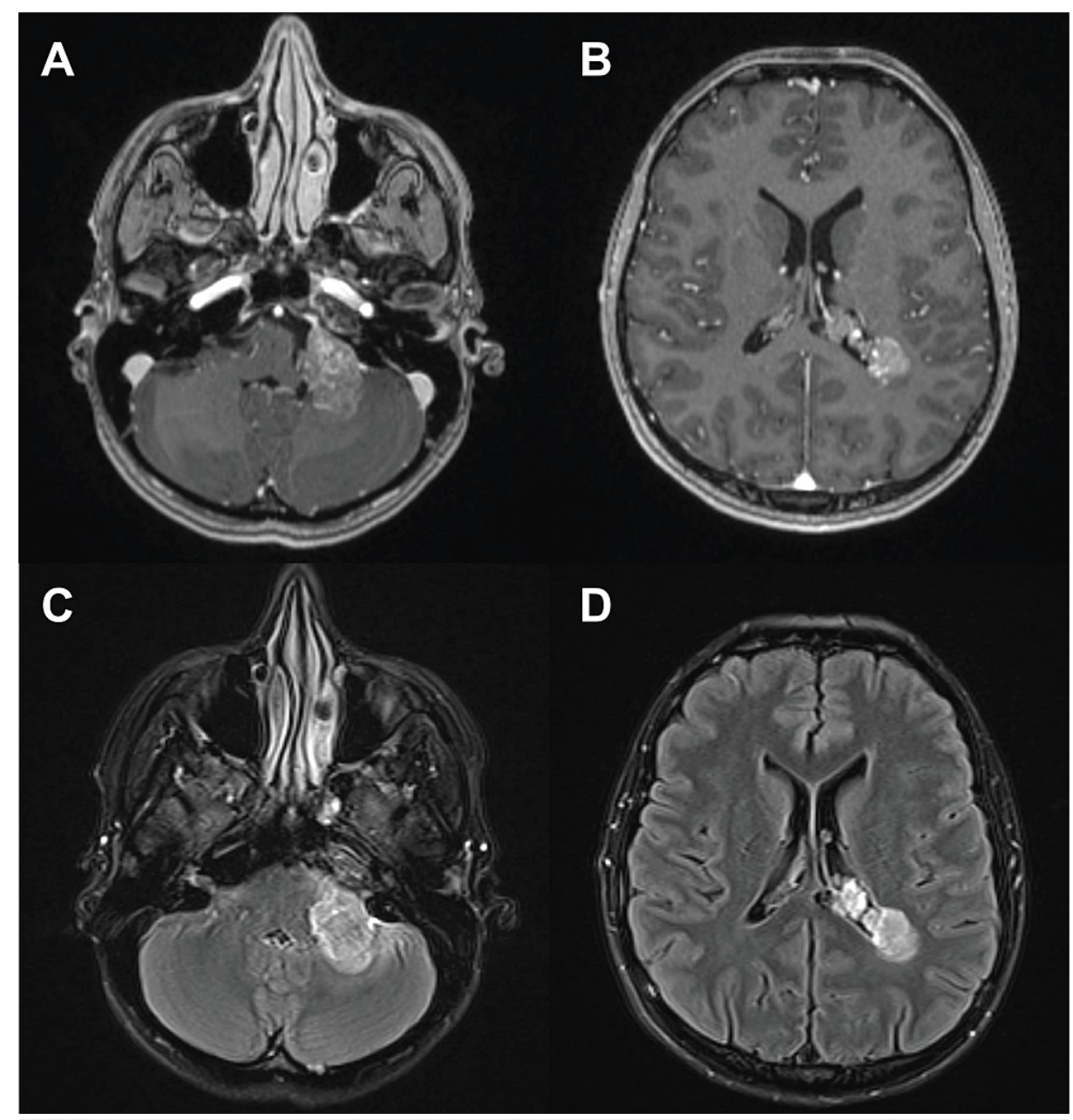

\section{FIGURE 1: Preoperative brain MRI of the patient}

(A) Axial view of the left CPA mass located on T1. (B) Axial view of the lesion located in the atrium of the left ventricle on T1. (C) Axial view of the left CPA mass on T2-FLAIR. (D) Axial view of the left ventricle lesion on T2-FLAIR.

MRI: magnetic resonance imaging; CPA: cerebellopontine angle; T2-FLAIR: T2-weighted-fluid-attenuated inversion recovery

\section{Operative description}

The patient was positioned in the lateral position with the left side up. Cranial nerves 7-12 were monitored. An intraoperative lumbar puncture was performed for brain relaxation, and CSF was sent for cytological analysis. A $10 \mathrm{~cm}$ curvilinear incision was placed just below an imaginary line between the inion and external auditory canal. A single burr hole was made at the transverse-sigmoid junction, followed by a small retromastoid craniotomy. The craniotomy edges were burred until the edge of the transverse and sigmoid sinuses were visualized. The dura was opened in a $\mathrm{C}$ fashion along the transverse sigmoid junction. Using the interoperative microscope, we removed a large section of the tumor and sent it for frozen and permanent pathological specimen. The tumor was debulked utilizing the ultrasonic aspirator while frequently checking the tumor capsule for cranial nerve function using the monopolar Prass probe (Medtronic, Fridley, Minnesota). There was significant tumor adherence to surrounding vessels and cranial nerves. The intraoperative frozen pathology report was consistent with metastatic adenocarcinoma. Given the significant adherence of the tumor to the cerebellum and cranial nerves, we decided to leave the remaining tumor to avoid cranial nerve deficit. The bone flap was replaced at the end of the procedure. Routine postoperative CT was performed (Figure 2). 


\section{Cureus}

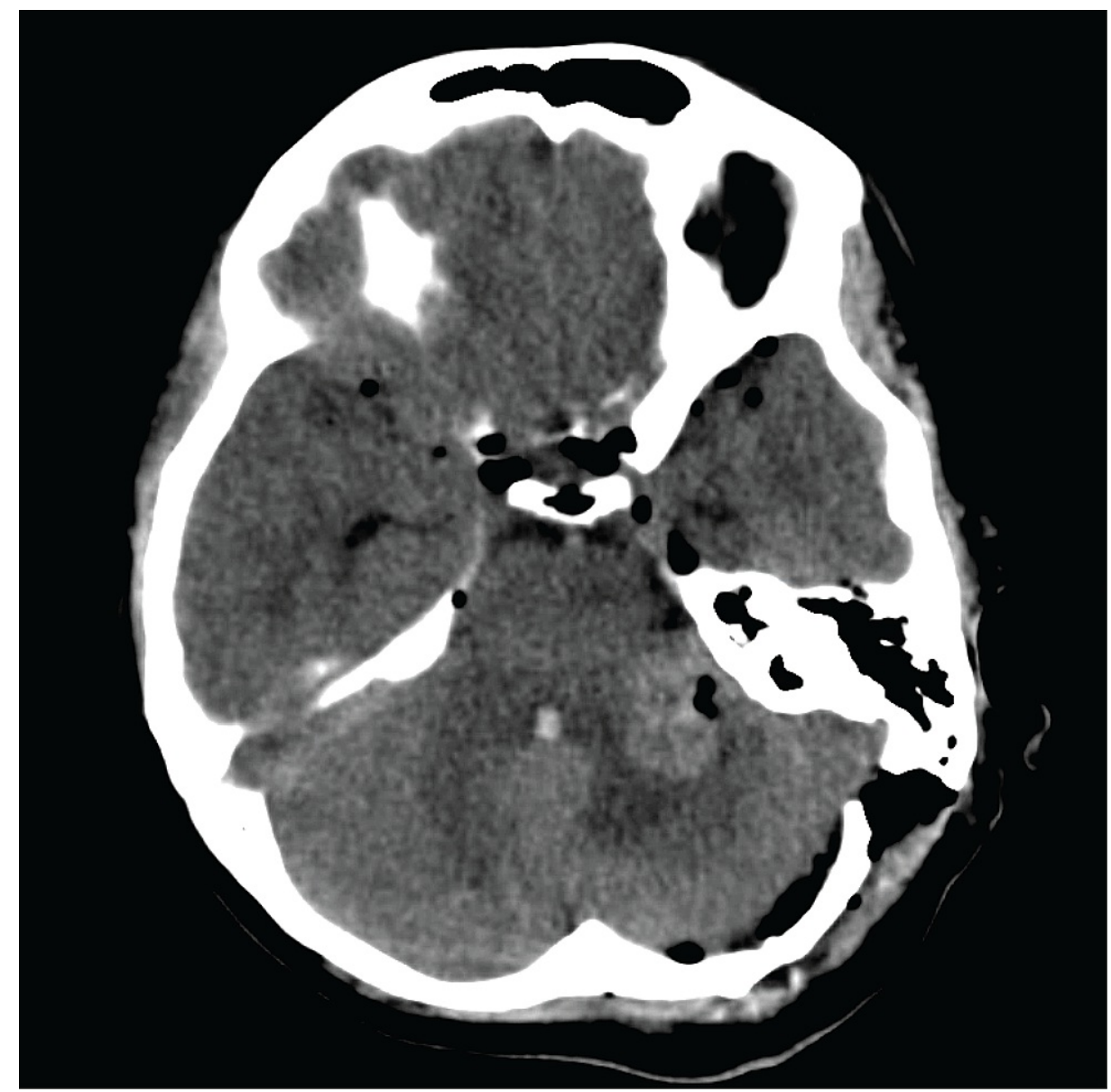

\section{FIGURE 2: Postoperative brain CT of the patient}

The left retromastoid entry point is visualized by the defect in the temporal bone. Subtotal resection of the tumor shows decompression of the CPA.

CT: computed tomography; CPA: cerebellopontine angle

\section{Postoperative course}

The patient's preoperative left visual acuity and facial paresthesia resolved. Her hearing loss remained after surgery. She was otherwise neurologically intact. The patient left against medical advice prior to postoperative MRI and has not reported for postoperative or oncologic follow-up.

\section{Pathological findings}

The tumor consisted of pleomorphic epithelial cells, frequently with vacuolated cytoplasm, arranged in a well-defined papillary pattern (Figures 3A-3F). The tumor cells were positive for AE1/AE3, CK7, prealbumin (transthyretin), S100, synaptophysin, and vimentin. They were negative for CEA, CK20, EMA, ER, GATA3, GFAP, Napsin A, p16, PAX8, TTF1, and WT-1. Rare scattered cells were positive for p53. The Ki67 index was visually assessed as $30 \%-40 \%$. The special stains and immunohistochemical preparations exclude both ependymoma and adenocarcinoma and were consistent with primary choroid plexus carcinoma, WHO grade III. 


\section{Cureus}
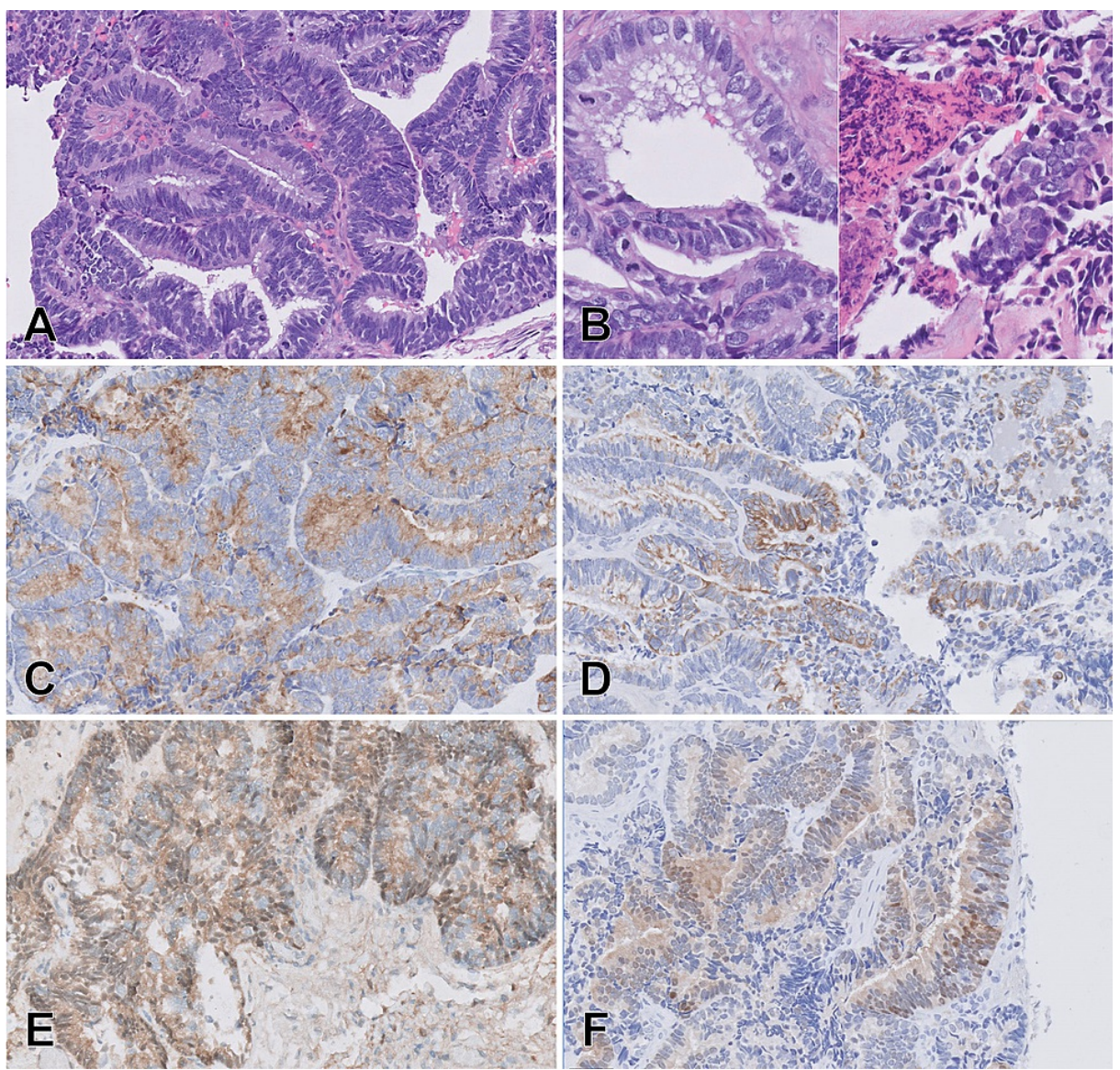

\section{FIGURE 3: Photomicrographs of immunohistochemically stained choroid plexus carcinoma surgical specimens}

(A) H\&E, 20x. (B) Increased mitotic activity and necrosis, H\&E, 40x. By immunohistochemistry, the tumor cells are positive for (C) CK7, 20x; (D) S100, 20x; (E) transthyretin, 20x; and (F) synaptophysin, 20x.

\section{Discussion}

Choroid plexus carcinoma is a highly aggressive, malignant tumor that is more common in pediatrics than in adults. To our knowledge, this is the first case report of CPC presenting in the CPA of an adult patient.

CPC stains positive for cytokeratin and has a variable expression for vimentin, S100, transthyretin, and glial fibrillary acidic protein. CPC is typically negative for epithelial membrane antigen. Our patient was positive for CK7, S100, vimentin, and transthyretin while negative for glial fibrillary acidic protein and epithelial membrane antigen. Gross pathology will usually show a friable papillary or cauliflower-like appearance. Papillary ependymoma is a rare variant of ependymoma and often gives rise to confusion with choroid plexus tumors because of topographic, light microscopic, and ultrastructural similarities.

Immunohistochemistry for our patient also revealed scattered p53 positivity. Many cases of choroid plexus carcinoma are associated with Li-Fraumeni syndrome, an autosomal dominant disorder involving a mutation in the germ cell line of p 53 tumor suppressor genes [4]. Roughly 50\%-60\% of patients with CPC were observed to have TP53 gene mutations [5]. Her extended neuro-oncology gene panel reported a positive BCL6 corepressor (BCOR) gene mutation. BCOR gene mutations have rarely occurred in high-grade neoplasms but have never been linked directly with a case of CPC [5-6].

CPCs arise from modified ependymal cells surrounding a core of capillaries and loose connective tissue. CPCs are typically intraventricular, however, extraventricular tumors have been reported [7-9]. Ectopic sites are not commonly reported but include the suprasellar region, foramen magnum, and spinal canal in the absence of other intracranial lesions [10]. Ectopic CPC is thought to arise through CSF dissemination [10]. Our literature search found only two occurrences of cerebellopontine angle CPCs; both had an invasion of CPC from the fourth ventricle through the foramen of Luschka into the CPA [11-12]. The most common site for adults is in the fourth ventricle (63\%) while in the pediatric group is the lateral ventricle (72\%) [10]. Presentation with multiple CPCs is rare, occurring in only $5 \%$ of CPC patients [9]. Metastatic lesions have a higher frequency of being supratentorial [10]. Our patient uniquely presented with a primary CPC in the atrium of the left ventricle and ectopic in the CPA without any invasion from the fourth ventricle. Her 
metastatic lesions were supratentorial in the left foramen of Monroe and the right internal auditory canal. CPC is an aggressive type of brain tumor and should remain on differentials where primary tumors present intraventricularly and in ectopic regions on imaging in adults.

The symptoms of CPC typically relate to progressive obstructive hydrocephalus due to their intraventricular location. Headache, diplopia, nausea, vomiting, and ataxia are the most common presenting symptoms (Table 1). However, when CPC tumors invade into rare locations, such as the CPA, headache and hearing problems start first, followed by gait disturbance, facial nerve involvement, and visual field deficits. Our patient had hearing loss and facial hypesthesia, which is much more common with CPA-based tumors.

\begin{tabular}{|c|c|c|c|c|c|c|c|c|}
\hline Study & Age/Sex & $\begin{array}{l}\text { Symptom } \\
\text { Duration }\end{array}$ & Clinical Features & Location & $\begin{array}{l}\text { Craniotomy } \\
\text { Location }\end{array}$ & $\begin{array}{l}\text { Surgical } \\
\text { Result }\end{array}$ & $\begin{array}{l}\text { Adjuvant } \\
\text { Therapy }\end{array}$ & Outcome \\
\hline $\begin{array}{l}\text { Tham et } \\
\text { al [12] }\end{array}$ & $66 / F$ & $3 \mathrm{mon}$ & $\begin{array}{l}\text { Left facial hemiparesis, dizziness, } \\
\text { headache }\end{array}$ & $\begin{array}{l}\text { FV through the } \\
\text { foramen of Luschka } \\
\text { into the CPA }\end{array}$ & Suboccipital & Biopsy & None & $\begin{array}{l}\text { Expired } 2 \text { days } \\
\text { after the } \\
\text { operation }\end{array}$ \\
\hline $\begin{array}{l}\text { Izci et al } \\
{[14]}\end{array}$ & $54 / \mathrm{M}$ & $\sim$ & Headache, visual, gait disturbances & R LV & Transcallosal & GTR & RT & $\begin{array}{l}\text { Expired } 12 \\
\text { mon after } \\
\text { surgery }\end{array}$ \\
\hline $\begin{array}{l}\text { Osada et } \\
\text { al [15] }\end{array}$ & $53 / \mathrm{M}$ & 5 mon & Gait disturbance, $\mathrm{L}$ hemiparesis & R LV & Superior Parietal & SR & $\mathrm{RT}$ & $\begin{array}{l}\text { No evidence of } \\
\text { recurrence } 7 \\
\text { mon after the } \\
\text { operation }\end{array}$ \\
\hline $\begin{array}{l}\text { Tena- } \\
\text { Suck } \\
\text { et al [16] }\end{array}$ & 18/M & $12 \mathrm{mon}$ & $\begin{array}{l}\text { Headache, nausea, vomiting, visual } \\
\text { disturbance, diplopia, ataxic gait, } \\
\text { L-sided hemiparesis }\end{array}$ & $\mathrm{FV}$ & Suboccipital & GTR & None & $\begin{array}{l}\text { No evidence of } \\
\text { recurrence } 2 \\
\text { years after the } \\
\text { operation }\end{array}$ \\
\hline $\begin{array}{l}\text { Lozier } \\
\text { et al [7] }\end{array}$ & 68/F & $8 \mathrm{mon}$ & $\begin{array}{l}\text { Mild expressive aphasia, confusion, } \\
\text { difficulty concentrating }\end{array}$ & $\begin{array}{l}\text { L anterior temporal } \\
\text { (extraventricular) }\end{array}$ & Frontotemporal & GTR & $\begin{array}{l}\text { CT and } \\
\text { RT }\end{array}$ & $\begin{array}{l}\text { No evidence of } \\
\text { recurrence } 4 \\
\text { years after the } \\
\text { operation }\end{array}$ \\
\hline $\begin{array}{l}\text { Kishore } \\
\text { et al [4] }\end{array}$ & $24 / \mathrm{M}$ & 2 mon & Headache, nausea, vomiting & R LV (temporal horn) & Parietal & GTR & RT & $\sim$ \\
\hline $\begin{array}{l}\text { Yip et al } \\
\text { [17] }\end{array}$ & $21 / \mathrm{M}$ & $1 \mathrm{mon}$ & Headache & $\begin{array}{l}\text { L LV (trigone and } \\
\text { occipital horn) }\end{array}$ & $\begin{array}{l}\text { Occipitoparietal, } \\
\text { posterior } \\
\text { interhemispheric } \\
\text { precuneus }\end{array}$ & GTR & $\begin{array}{l}\text { CT and } \\
\text { RT }\end{array}$ & $\begin{array}{l}\text { No evidence of } \\
\text { recurrence } 2 \\
\text { years after the } \\
\text { operation }\end{array}$ \\
\hline $\begin{array}{l}\text { Ozdogan } \\
\text { et al [18] }\end{array}$ & 73/M & $\sim$ & Headache & FV & Transcortical & GTR & None & $\sim$ \\
\hline $\begin{array}{l}\text { Bohara } \\
\text { et al [3] }\end{array}$ & 60/M & $\sim$ & Headache & R LV (trigone) & $\begin{array}{l}\text { Transcortical, middle } \\
\text { temporal gyrus }\end{array}$ & SR & $\begin{array}{l}\text { CT and } \\
\text { RT }\end{array}$ & $\begin{array}{l}\text { Expired } 13 \\
\text { mon after the } \\
\text { operation }\end{array}$ \\
\hline $\begin{array}{l}\text { Guo et al } \\
{[8]}\end{array}$ & 59/M & $1 \mathrm{mon}$ & Speech delay & $\begin{array}{l}\text { L temporoparietal } \\
\text { (extraventricular) }\end{array}$ & Temporoparietal & GTR & $\begin{array}{l}\text { CT and } \\
\text { RT }\end{array}$ & $\begin{array}{l}\text { Recurred } 6 \\
\text { mon after } \\
\text { resection }\end{array}$ \\
\hline $\begin{array}{l}\text { Pellerino } \\
\text { et al [19] }\end{array}$ & 50/M & $\sim$ & $\begin{array}{l}\text { Dizziness, progressive gait } \\
\text { disturbance }\end{array}$ & FV & $\sim$ & GTR & $\begin{array}{l}\text { CT and } \\
\text { RT }\end{array}$ & $\begin{array}{l}\text { Recurred } 8 \\
\text { years after } \\
\text { resection }\end{array}$ \\
\hline $\begin{array}{l}\text { Zhu et al } \\
\text { [20] }\end{array}$ & $34 / \mathrm{F}$ & $\sim$ & Headache, double vision, nausea & L LV & $\sim$ & GTR & $\mathrm{RT}$ & $\sim$ \\
\hline $\begin{array}{l}\text { Azhani } \\
\text { et al [10] }\end{array}$ & 39/M & 2 weeks & Headache, L hemiparesis & R temporoparietal & Trans-sylvian & SR & $\sim$ & $\begin{array}{l}\text { Expired } 2 \\
\text { weeks after } \\
\text { surgery }\end{array}$ \\
\hline $\begin{array}{l}\text { Kim et al } \\
{[9]}\end{array}$ & $49 / F$ & 1 week & $\begin{array}{l}\text { Visual disturbance, generalized } \\
\text { tonic-clonic seizure }\end{array}$ & $\begin{array}{l}\text { Temporoparietal } \\
\text { (extraventricular) }\end{array}$ & $\begin{array}{l}\text { Transcortical via } \\
\text { parieto-occipital } \\
\text { junction }\end{array}$ & GTR & CT & $\begin{array}{l}\text { No evidence of } \\
\text { recurrence } 10 \\
\text { mon after the } \\
\text { operation }\end{array}$ \\
\hline
\end{tabular}




\section{Cureus}

\begin{tabular}{|c|c|c|c|c|c|c|c|c|}
\hline & 40/M & $\sim$ & Dizziness, nausea, and headache & FV, tectum & $\sim$ & SR & $\begin{array}{l}\text { CT and } \\
\text { RT }\end{array}$ & $\begin{array}{l}\text { Expired } 11 \\
\text { mon after the } \\
\text { operation }\end{array}$ \\
\hline $\begin{array}{l}\text { This } \\
\text { study }\end{array}$ & $33 / F$ & 4 mon & $\begin{array}{l}\text { Headache, L-sided hearing loss, L } \\
\text { paresthesias, L vision loss }\end{array}$ & $\begin{array}{l}\text { L CPA, R IAC, L LV } \\
\text { (atrium), and L } \\
\text { foramen of Monroe }\end{array}$ & Retromastoid & SR & TBD & $\sim$ \\
\hline
\end{tabular}

TABLE 1: Summary of cases reported as choroid plexus carcinoma

FV: fourth ventricle, LV: lateral ventricle, R: right, L: left, GTR: gross total resection; SR: subtotal resection; CT: chemotherapy, RT: radiation therapy

Adjuvant therapy for CPC is controversial. In 2009, Wrede published a meta-analysis showing chemotherapy improved the survival of patients with resected CPC. Patients with CPC receiving combined radiation and chemotherapy had the best two-year survival (63\%), followed by those with chemotherapy alone (45\%), radiotherapy alone (32\%), and those without further therapy (15\%) [13]. Various agents have been shown to reduce the size of CPCs after resection such as cisplatin, etoposide, cyclophosphamide, procarbazine, carboplatin, methotrexate, doxorubicin, and vincristine [13]. With its rarity, adjuvant chemotherapy after resection remains controversial as the standard of care for patients with CPC [2]. Although the mainstay of treatment of CPC tumors is attempting a gross total resection, post-resection chemotherapy and radiation should be considered as a rational treatment option to improve outcomes.

\section{Conclusions}

Choroid plexus carcinoma presenting in the CPA is extremely rare. Gross total surgical resection was limited due to cranial nerve invasion. This is the first reported case of a primary CPC occurring within the CPA in an adult. The unique presentation and progression of this rare adult-onset CPC provide insight for the diagnosis and treatment of other rare instances of CPTs.

\section{Additional Information \\ Disclosures}

Human subjects: Consent was obtained or waived by all participants in this study. Conflicts of interest: In compliance with the ICMJE uniform disclosure form, all authors declare the following: Payment/services info: All authors have declared that no financial support was received from any organization for the submitted work. Financial relationships: All authors have declared that they have no financial relationships at present or within the previous three years with any organizations that might have an interest in the submitted work. Other relationships: All authors have declared that there are no other relationships or activities that could appear to have influenced the submitted work.

\section{References}

1. Sun MZ, Oh MC, Ivan ME, et al.: Current management of choroid plexus carcinomas . Neurosurg Rev. 2014, 37:179-192. 10.1007/s10143-013-0499-1

2. Mishra A, Srivastava C, Singh SK, Chandra A, Ojha BK: Choroid plexus carcinoma: case report and review of literature. J Pediatr Neurosci. 2012, 7:71-73. 10.4103/1817-1745.97633

3. Bohara M, Hirabaru M, Fujio S, et al.: Choroid plexus tumors: experience of 10 cases with special references to adult cases. Neurol Med Chir (Tokyo). 2015, 55:891-900. 10.2176/nmc.oa.2015-0126

4. Kishore S, Negi G, Meena H, Anuradha K, Pathak PV, Bansal K: Choroid plexus carcinoma in an adult. J Neurosci Rural Pract. 2012, 3:71-73. 10.4103/0976-3147.91952

5. Chiang JC, Ellison DW: Molecular pathology of paediatric central nervous system tumours . J Pathol. 2017, 241:159-172. 10.1002/path.4813

6. Sturm D, Orr BA, Toprak UH, et al.: New brain tumor entities emerge from molecular classification of CNSPNETs. Cell. 2016, 164:1060-1072. 10.1016/j.cell.2016.01.015

7. Lozier AP, Arbaje YM, Scheithauer BW: Supratentorial, extraventricular choroid plexus carcinoma in an adult: case report. Neurosurgery. 2009, 65:816-817. 10.1227/01.Neu.0000348291.48810.C2

8. Guo P, Tang W, Li S, Li H, Cheng L, Feng Y, Yu Y: Choroid plexus carcinoma in the external ventricle of an adult. J Craniofac Surg. 2015, 26:664-666. 10.1097/scs.0000000000002103

9. Kim T, Park MR, Hong EK, Gwak HS: Choroid plexus carcinoma in adults: two case reports . Brain Tumor Res Treat. 2019, 7:48-52. 10.14791/btrt.2019.7.e23

10. Azhani C, Chan K, Fadli M, Saufi A: Choroid plexus carcinoma: a case report and literature review . Surgery and Rehabilitation. 2017, [Epub]:10.15761/SRJ.1000108

11. Samuel TA, Parikh J, Sharma S, et al.: Recurrent adult choroid plexus carcinoma treated with high-dose chemotherapy and syngeneic stem cell (bone marrow) transplant. J Neurol Surg A Cent Eur Neurosurg. 2013, 74:149-154. 10.1055/s-0032-1333419

12. Toe TK, Lai WH, Bee TT: A case of papillary adenocarcinoma of the choroid plexus . J Pathol. 1969, 99:321324. 10.1002/path. 1710990408 


\section{Cureus}

13. Wrede B, Liu P, Wolff JE: Chemotherapy improves the survival of patients with choroid plexus carcinoma: a meta-analysis of individual cases with choroid plexus tumors. J Neurooncol. 2007, 85:345-351. 10.1007/s11060-007-9428-x

14. Izci Y, Gürkanlar D, Öngürü Ö, Timurkaynak E: Choroid plexus carcinoma in an adult patient: case report . Turk Neurosurg. 2005, 15:105-108.

15. Osada H, Mori K, Yamamoto T, Nakao Y, Wada R, Maeda M: Choroid plexus carcinoma secreting carbohydrate antigen 19-9 in an adult. Case report. Neurol Med Chir (Tokyo). 2006, 46:251-253. 10.2176/nmc.46.251

16. Tena-Suck ML, Gómez-Amador JL, Ortiz-Plata A, Salina-Lara C, Rembao-Bojórquez D, Vega-Orozco R: Rhabdoid choroid plexus carcinoma: a rare histological type . Arq Neuropsiquiatr. 2007, 65:705-709. 10.1590/s0004-282x2007000400032

17. Yip C-M, Tseng H-H, Hsu S-S: Choroid plexus carcinoma: a rare tumor in adult . Surg Sci. 2014, 5:146-149. 10.4236/ss.2014.54026

18. Ozdogan S, Gergin YE, Gergin S, Senol O, Tiryaki M, Tatarli N, Hicdonmez T: Choroid plexus carcinoma in adults: an extremely rare case. Pan Afr Med J. 2015, 20:302. 10.11604/pamj.2015.20.302.5854

19. Pellerino A, Cassoni P, Boldorini R, Pinessi L, Rudà R: Response to combined radiotherapy and chemotherapy of a leptomeningeal spread from choroid plexus carcinoma: case report. Neurol Sci. 2015, 36:639-641. 10.1007/s10072-014-1983-2

20. Zhu VW, Hinduja S, Knezevich SR, Silveira WR, DeLozier CD: A rare case of choroid plexus carcinoma that led to the diagnosis of Lynch syndrome (hereditary nonpolyposis colorectal cancer). Clin Neurol Neurosurg. 2017, 158:46-48. 10.1016/i.clineuro.2017.04.013 